ХАРАКТЕРИСТИКА НАУКОВОЇ ПРОДУКЦІЇ З ПРОБЛЕМ УПРАВЛІННЯ
ОСВІТОЮ ЯК ПОКАЗНИК РОЗВИТКУ ТЕОРІЇ УПРАВЛІННЯ ОСВІТОЮ

\title{
CHARACTERISTICS OF SCIENTIFIC PRODUCTION ON EDUCATION MANAGEMENT PROBLEMS AS AN INDICATOR OF THE DEVELOPMENT OF EDUCATION MANAGEMENT THEORY
}

\begin{abstract}
y статті надаються кількісні та якісні характеристики наукової продукції з питань управління освітою, що свідчить про розвиток теорії управління освітою у певні періоди та сорормованість кола науковців, які займаються дослідженням проблематики у галузі управління освітою. Ґрунтовно проаналізовано різні типи наукової продукції, а саме: книги (підручники, посібники, методичні рекомендації, тематичні словники, довідники, тези доповідей та виступів, тематичні збірники праць, звіти про наукові дослідження та ін.), наукові статmі та дисертації. Автором наводяться результати аналізу кількості захищених дисертацій з педагогічних спеціальностей (13.00.01, 13.00.04, 13.00.06), динаміка зростання кількості статей, книжкової продукції за різними видами (одноосібних праць, робіт у співавторстві та збірників праць, навчально-методичної та науково-методичної літератури) за сімома періодами, де 1-й період - 50-mi p. XX cm.; 2-й період 60-mi p. XX cm., 3-й період - 70-mi p. XX cm., 4-ŭ період - 80-mi p. XX cm., 5-й період 90-mi p. XX cm., 6-й період - 2000-2007 рp., 7-й період - 2008-2018 рр. Автор визначає науковців, яким притаманна найбільша наукова активність у галузі дослідження проблем управління освітою за визначеними періодами, визначає політичні, економічні, соціальні передумови, які вплинули на формування наукової спільноти, що займається дослідженнями у галузі управління освітою. Виявляє закономірності щодо зростання кількості наукової продукції 3 проблем управління освітою у певні періоди відповідно до розвитку вітчизняної системи освіти, формування нормативно-правової бази у освітній галузі тощо. Автором зроблено висновки, що результати аналізу кількісних та якісних характеристик наукової продукції з проблем управління освітою свідчать про сфрормованість наукової спільноти, яка займається дослідженням иієї проблематики, та розвиток наукової галузі управління освітою.

Ключові слова: управління освітою, наукова продукція, наукові дослідження, розвиток теорії управління освітою.
\end{abstract}

The article presents the quantitative and qualitative characteristics of scientific products in the field of education management, which testifies the development of the theory of education management in certain periods and the formation of a circle of scientists involved in research issues in the field of education management. Different types of scientific products are thoroughly analyzed, namely books (textbooks, manuals, methodical recommendations, thematic dictionaries, reference books, abstracts and speeches, thematic collections of works, reports on scientific research, etc.), scientific articles and dissertations. The author presents the results of the analysis of the number of approved theses in pedagogical specialties (13.00.01, 13.00.04, 13.00.06), the dynamics of the growth of the number of articles, book products by various types (individual works, works in co-authorship and collections of works, educational, methodological and scientific-methodical literature) for the seven periods, where the 1st period - 50s years of the 20th century; the 2nd period - 60s years of the 20th century, the 3rd period - 70 years of the 20th century, the 4th period-80s years of the 20th century, the 5th period - 90s years of the 20th century, the 6th period -2000-2007, the 7th period2008-2018. The author defines the scholars who had the greatest scientific activity in the field of study of education management problems in those periods, defines the political, economic, and social preconditions that influenced the formation of the scientific community that is engaged in research in the field of education management, reveals regularities regarding the growth of the quantity of scientific products on the problems of education management in certain periods in accordance with the development of the domestic system of education, the formation of a regulatory and legal framework in the educational field, and so on. The author concludes that the results of the analysis of quantitative and qualitative characteristics of scientific products on the problems of education management show the formation of the scientific community, which is engaged in the research of this problem, and the development of scientific branch of education management.

Key words: education management, scientific products, scientific researches, development of the theory of education management.
Постановка проблеми у загальному вигляді. Теорія управління освітою розвивалася тривалий час як складник педагогічної теорії. Проте підвищення ролі управління освітніми установами, акумуляція інорормації з цього напряму, наукової продукції з проблем управління освітою тощо, збільшення кількості науковців, які спеціалізуються на дослідженні цих проблем, відкриття у 2006 р. спеціальності 13.00.06 з підготовки науковців, які досліджують теорію і методику управління освітою, сприяло формуванню вітчизняної теорії управління освітою як окремої наукової галузі. Кількісні та якісні характеристики наукової продукції з питань управління освітою відбивають розвиток теорії управління освітою у певні періоди та срормування наукової спільноти, яка займається дослідженням проблематики у галузі управління освітою.

Аналіз останніх досліджень і публікацій. Ґрунтовний аналіз наукової продукції з проблем управління освітою здійснено у дисертаційному дослідженні на здобуття наукового ступеня 
доктора педагогічних наук О. Адаменко «Розвиток педагогічної науки в Україні в другій половині XX ст. (1950-2000рр.)» [1]. Аналіз наукової продукції 3 питань управління освітою здійснювався у дисертаційних дослідженнях на здобуття наукового ступеня кандидата педагогічних наук Н. Васиньової «Розвиток теорії управління вищими навчальними закладами в Україні (остання чверть XX - початок XXI століття)» [2] та І. Ситар «Розвиток теорії та технологій управління загальноосвітніми навчальними закладами в Україні (1991-2016 роки)» [9].

Виділення не вирішених раніше частин загальної проблеми. У названих дослідженнях аналізувалася наукова продукція 3 управління окремими типами закладів освіти у певні періоди. У науковій літературі відсутній комплексний аналіз наукової продукції 3 проблем управління освітою 3 1950-х років до нашого часу. Проведення цього дослідження необхідно для формування цілісного уявлення щодо розвитку теорії управління освітою.

Мета статті - надати кількісну та якісну характеристику наукової продукції, у якій розглядаються проблеми управління освітою.

Виклад основного матеріалу. Аналіз наукової продукції з проблеми управління освітою здійснювався за такими напрямами: книги (підручники, посібники, методичні рекомендації, тематичні словники, довідники, тези доповідей та виступів, тематичні збірники праць, звіти про наукові дослідження та ін.), наукові статті та дисертації.

До відкриття у вітчизняному науковому полі у 2006 р. спеціальності 13.00.06 «Теорія і методика управління освітою» як самостійного наукового напряму педагогічних досліджень [6] проблеми управління освітою досліджувалися загальною теорією педагогіки в межах школознавства, соціального та державного управління. Аналіз кількості захищених дисертацій за десятиріччями 3 педагогічних спеціальностей (13.00.01, 13.00.04, 13.00.06) за періодами наведено у рис. 1., де 1-й період - 50-ті р. XX ст.; 2-й період - 60-ті р. XX ст., 3-й період - 70-ті р. XX ст., 4-й період 80-тір. XX ст., 5-й період-90-тір. XX ст., 6-й період2000-2007 рр., 7-й період - 2008-2018 рр.

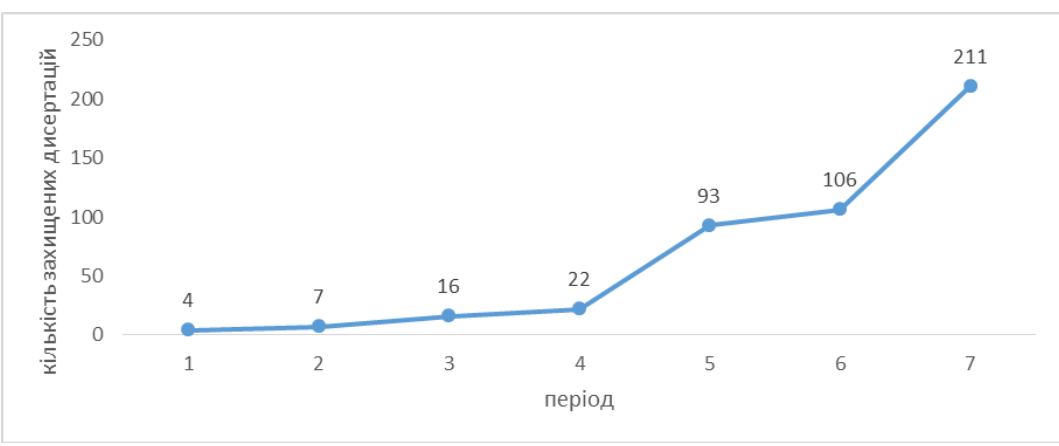

Рис. 1. Захищені дисертації зі спеціальностей 13.00.01, 13.00.04, 13.00 .06$, у яких досліджувалися проблеми управління освітою та розвитку освіти за періодами
Стрімке збільшення захищених дисертацій відбувається у 1990-ті роки (93), якщо навіть об'єднати кількість робіт за попередні десятиріччя (49). Також кількість дисертацій стрімко зростає після введення нової спеціальності до 211 робіт, 3 яких 140 - дисертації під шифром 13.00.06. Отже, на кінець 2018 р. коло науковців, які займаються проблематикою управління освітою та підтвердили свою кваліфрікацію захистом дисертацій, становить 459 учених, 3 них 74 - ґрунтовні докторські дослідження, більшість 3 яких, а саме 39 робіт (53\%), захищено в останнє десятиріччя (2008-2018 рр.).

Книги та публікації з проблем управління освітою у 1950-1970-ті роки проаналізовано у роботі О. Адаменко [1]. У 1950-ті роки науковець виділяє 31 книгу та 63 статті з проблем управління освітою. Серед книг є збірники статей, праці у співавторстві (16 книг); роботи навчально-методичного складу (стенографрія лекцій, методична збірка); індивідуальні праці (15 книг). Найбільша наукова активність у галузі дослідження проблем управління освітою у ці роки була притаманна А. Бондару, М. Данилевському, Є. Березняку, особливо слід відзначити монографії та публікації В. Сухомлинського та М. Черпінського, які значно вплинули на розвиток вітчизняної теорії управління освітою.

У 1960-ті роки опубліковано 32 книги та 92 статті. Найбільша наукова активність у галузі дослідження проблем управління освітою була притаманна В. Сухомлинському, М. Черпінському, $€$. Березняку, М. Бойко, С. Полгороднику, А. Бондарю, Б. Кобзарю. Серед наукових праць цього періоду частину становлять одноосібні роботи (19 робіт), другу частину (13 робіт) - збірники статей та роботи у співавторстві. До робіт навчальнометодичного спрямування належать матеріали до наради, методичне письмо, методичні вказівки.

У 1970 р. видано 13 книг та 157 статей. Більшість книг - одноосібні праці (9), видаються роботи навчально-методичного спрямування (2 посібники, інструктивно-методичний лист, методичні рекомендації), збірники статей та праці у співавторстві. Продовжують свою наукову діяльність М. Черпінський, Є. Березняк, В. Сухомлинський, А. Бондар, Б. Кобзар, С. Полгородник. Розпочинає свою наукову діяльність В. Маслов. Низку статей видають Б. Андрієвський, Р. Винник, П. Дроб'язко, М. Красовицький, О. Матвієнко, І. Пелипейко, І. Синиця, В. Стіоса, В. Чабан, Р. Шакуров та ін.

У 1980-ті роки видано 49 книг та 104 статті. Розширюється коло видань. Порівняно 3 попереднім десятиріччям зменшилася загальна кількість публікацій з про- 
блем управління освітою. Спираючись на отримані результати, О. Адаменко пов'язує це з кризовими проявами у суспільстві й освіті, які створили умови для перегляду панівної за радянські часи освітньої та управлінської авторитарної парадигми, яка гуртувалася на ідеологічних настановах партії [1]. Продовжують свою плідну наукову діяльність Є. Березняк, А. Бондар, Б. Кобзар, В. Маслов, Р. Шакуров та ін. Розпочинають свою наукову діяльність В. Пікельна, Б. Коротяєв, В. Бегей, М. Поташник, Є. Хриков та ін. Співвідношення виду наукової продукції зберігається, як у попереднє десятиріччя (21 - одноосібні праці, 28 - у співавторстві, збірники статей). Проте збільшилася кількість праць методичного складу (16 робіт), 3'явилися збірники матеріалів конференцій.

1990-ті роки насамперед пов'язують із фрормуванням національної системи освіти та національного наукового простору. Починаючи з 1991 року розвиток теорії управління освітою відбувається у науковому просторі незалежної України. У цей час відбувається зростання кількісних показників розвитку теорії управління освітою: значно зростає кількість книг (83) та публікацій (175). 383 книг тільки 41 видано авторами одноосібно, інші - у співавторстві. Збільшилася кількість колективних праць, у яких узагальнюються провідні ідеї колективів авторів. Прикладом такого виду наукової продукції $€$ колективна монограсрія «Повышение квалиорикации педагогических кадров» [4] під редакцією І. Жерносека, у якій узагальнено досвід творчого колективу Центрального інституту удосконалення вчителів (ЦУУ) Міністерства народної освіти УРСР у складі таких авторів: І. Жерносека, В. Бондаря, В. Маслова, Н. Коломінського, М. Красовицького, С. Крисюка та ін. Ще одним прикладом колективної роботи є праця харківських науковців «Наукові основи управління школою» під редакцією Г. Єльникової [5]. Колективні роботи виконуються переважно на базах ЗВО. За даними Державної служби статистики, загальна кількість академій, університетів, інститутів за 1990-ті роки зростає з 149 до 313 [3]. Саме в цей період створюється Академія педагогічних наук України, фрормується структура науково-дослідних інститутів, наукових лабораторій тощо, регламентуються процедури визначення тем наукових досліджень, присудження наукових ступенів та присвоєння вчених звань. Збільшується кількість робіт методичного складу для керівників навчальних закладів різного типу (10 робіт), науково-методичних та навчальних посібників для підготовки та підвищення кваліфікацій керівних кадрів (16 робіт), що, на нашу думку, пов'язано з відкриттям спеціального фракультету 3 перепідготовки зі спеціальності «Організатор освіти» 3 присвоєнням кваліфікації «Організатор освіти», яка мала бути забезпечена навчальною літературою. Друкуються збірники за результа- тами матеріалів конференцій. Найбільша наукова активність з розробки теорії управління освітою в 90-ті роки XX ст. була притаманна В. Алфімову, В. Бегею, Є. Березняку, В. Бондарю, Г. Єльниковій, В. Маслову, І. Жерносеку, О. Кобернику, Н. Коломінському, В. Пікельній, Т. Рабченюк, Є. Хрикову. Також у цей період друкують низку праць такі науковці, як: Л. Даниленко, В. Гуменюк, Л. Калініна, В. Крижко, В. Лунячек, О. Мармаза, Н. Островерхова, В. Олійник, О. Остапчук, А. Підласий та ін.

У період 2000-2007 рр. триває зростання кількісних показників розвитку теорії управління освітою. Незважаючи на скорочений період (7 років), опубліковано 124 книги та більше 120 статей. Серед книг: 80 - одноосібні праці (бібліографічний покажчик, 22 монограсрії, підручники, методичні посібники, навчально-методичні посібники та ін.); 44 книги видано у співавторстві, збільшується кількість праць, які об'єднують наробки колективів авторів, активніше видаються роботи методичного та навчального спрямування (43 праці). На нашу думку, це пов'язано з розширенням системи освіти. Так, на кінець 2007 р., за даними Державної служби статистики, система вищої освіти складається із 350 університетів, академій та інститутів [3]. Розширюється система підвищення кваліфікації педагогічних та керівних кадрів. Із 2001 р. вводиться нова спеціальність «Управління навчальним закладом» за освітньо-кваліфікаційним рівнем магістр, підготовка за якою вимагала забезпечення навчальною літературою. Удосконалюється процедура присудження наукових ступенів та присвоєння вчених звань, регламентуються вимоги до монографії, кількості публікацій у наукових фрахових журналах (для захисту докторської дисертації - мінімум 20, кандидатської дисертації - мінімум 3 статті) [8]. Ці фактори сприяють збільшенню обсягу монографій, видання яких стає умовою отримання наукового ступеня доктора наук, збільшенню кількості статей здобувачами наукових ступенів. Наукова активність з розробки проблем теорії управління у цей період була притаманна науковцям, які захистили докторські дисертації, видали монографії та надрукували низку статей, а саме: О. Адаменко, Л. Даниленко, Г. Єльниковій, В. Олійнику, Т. Сорочан, Л. Карамушки, В. Докучаєвій, Л. Ващенко, Т. Десятову, Л. Онищук. Продовжують свою наукову активність І. Жерносек, І. Мармаза, В. Маслов, Л. Калініна, В. Пікельна, Є. Хриков, Є. Березняк, В. Берека, В. Бондар та ін.

У 2008-2018 рр. продовжує зростати кількість наукової продукції за результатами досліджень проблем управління освітою. У цей період опубліковано більше 130 книг та 1000 статей. Таке стрімке збільшення кількості статей, на нашу думку, пов'язано зі зростанням у цей період кількості здобувачів наукових ступенів, збільшення 3 
2012 р. кількості мінімальних публікацій у наукових фрахових виданнях (із 3 до 5 обов'язкових статей) для отримання наукового ступеня кандидата наук [7]. Своєю чергою збільшення кількості здобувачів наукових ступенів має тісний зв'язок зі зростанням кількості ЗВО у цей період. Кількість книг у цей період не набуває такого зростання, як кількість статей. Цей вид наукової продукції узагальнює теоретичні знання та практичний досвід 3 управління освітою, вимагає ґрунтовної роботи від науковців, тому більше відбиває стан розвитку теорії управління освітою. 3 представлених 136 книг 61 - монографії, більшість 3 яких одноосібні й містять результати дисертаційних досліджень. У цей період значно зростає кількість колективних монографій (15), які узагальнюють напрацювання різних наукових шкіл: Харківської, Київської, Луганської, Сумської. Необхідно відзначити, що в національній науці сорормувалася наукова спільнота, яка розробляє теорію управління освітою. Так, свою наукову активність продовжують В. Олійник, Є. Хриков, В. Маслов, Г. Єльникова, Л. Калініна, Т. Сорочан та ін. Триває видавництво робіт навчально-методичної спрямованості (38 книги), набуває поширення розробка електронної продукції (електронні підручники, спецкурси, дистанційні курси тощо). Продовжують друкуватися збірники наукових праць, часописи, результати науководослідної роботи Інституту педагогіки АПН України, збірники за матеріалами наукових семінарів, конференцій, кількість яких зростає у зв'язку зі збільшенням кількості науково-практичних коноеренцій, присвячених розгляду проблем управління освітою у цей період. Загалом у цей період видано 71 одноосібну працю та 65 робіт у співавторстві. Динаміка зростання різних типів книжкової продукції наведена на рис. 2. за тими ж періодами.

Отже, розгляд динаміки зростання кількості різних типів книжкової продукції дає змогу зробити висновки, що у 60-ті-70-ті роки XX століття більшу частину становили одноосібні праці, у яких узагальнювався практичний досвід управління закла-

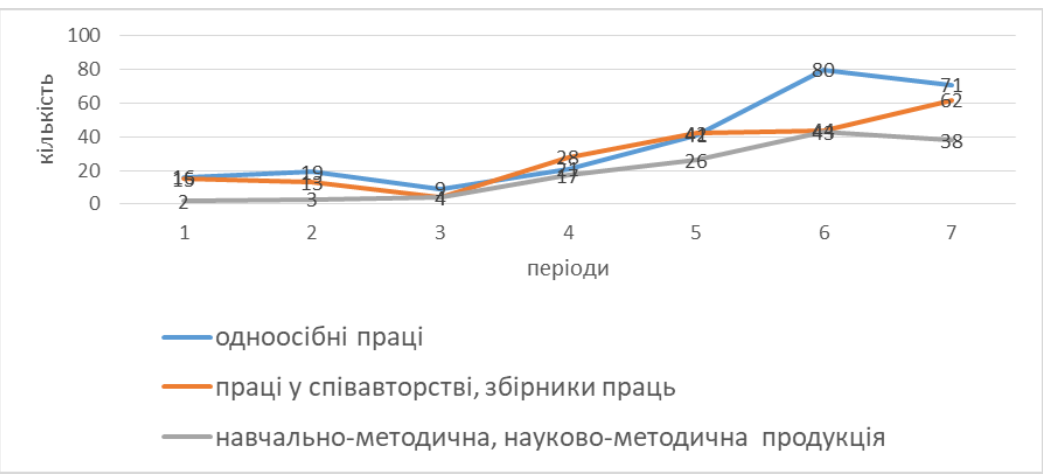

Рис. 2. Кількісне співвідношення різних типів книжкової продукції з проблем управління освітою за періодами

*навчально-методична та науково-методична продукція входить до перших двох груп книжкової продукції дами освіти, продукція навчально-методичного плану у цей період становить незначну частину. У 80-ті роки значно збільшується кількість робіт у співавторстві та збірників статей, зростає кількість навчально-методичних робіт. Для 90-х років характерне рівне співвідношення одноосібних праць та праць у співавторстві, продовжує зростати видання навчально-методичної літератури. У 2000-2007 рр. стрімко змінюється динаміка, вдвічі збільшується кількість одноосібних праць, серед яких значну частину становлять монографії здобувачів наукового ступеня доктора педагогічних наук, у яких узагальнюється теоретичне знання та практичні результати управління різними типами освітніх установ, майже вдвічі зростає кількість навчально-методичної літератури, яка має забезпечити навчання на нових управлінських спеціальностях у галузі освіти. Для 2008-2018 рр. характерне збільшення колективних праць, значну частину з яких становлять колективні монографрії як результат роботи колективів науковців та навчально-методична література, яка розробляється науковцями у співавторстві.

Узагальнюючий кількісний аналіз наукової продукції з проблематики управління освітою за періодами наведено на рис. 3.

За наведеними даними, майже у всі періоди більшість наукової продукції становлять статті. Так, у 50-ті та 70-ті роки XX століття кількість статей перевищує інші види наукової продукції у 3-5 разів. Дещо змінюється ситуація у 90-ті роки, коли кількість статей перевищує книжкову продукцію та дисертаційні роботи тільки вдвічі. Порівняно з 80-ми роками майже вдвічі збільшується кількість книжкової продукції та більше ніж у чотири рази збільшується кількість дисертацій, що свідчить про накопичення інсрормації з теорії управління освітою у цей період. Кардинально змінюється співвідношення у 2000-2007 роки, коли кількість книг перевищує кількість статей, а кількість дисертацій майже дорівнює кількості статей. Отже, саме 3 шостого періоду (2000-2007 рр.) збільшується кількість ґрунтовних робіт, відбувається узагальнення інорормації 3 теорії управління освітою. Ця тенденція характерна й для наступного періоду, проте саме у 2008-2018 роках стрімко зростає кількість статей, більшість 3 яких $€$ апробацією досліджень здобувачів наукових ступенів, кількість яких значно зростає у першій половині цього періоду.

Висновки. Кількісний аналіз наукової продукції з проблем управління освітою дає змогу зробити висновок, що в Україні сорормувалася наукова спільнота, яка розвиває 
теорію управління освітою та підтвердила свою кваліфрікацію захистом дисертаційних досліджень (459 учених). 3 них 74 - ґрунтовні докторські дослідження, більшість 3 яких (53\%) захищено в останнє десятиріччя (20082018 рр.). Розвиток теорії залежить від збільшення теоретичного й практичного знання, що відбивається у кількості здійснених наукових досліджень, виданих книг, статей. Наведені результати аналізу кількісних характеристик наукової продукції 3 проблем управління освітою свідчать про розвиток цієї наукової галузі. Проте важливим питанням залишається справжній внесок цих робіт у розвиток теорії, що значною мірою визначається якістю їх виконання. Якість досліджень залежить від методології їх здійснення та наявності нормативних вимог до доказовості результатів дослідження, що є важливим напрямом подальших досліджень.

\section{БІБЛІОГРАФІЧНИЙ СПИСОК:}

1. Адаменко О.В. Розвиток педагогічної науки в Україні в другій половині XX ст. (1950-2000рр.) : дис... д-ра пед. наук : 13.00.01. Луганськ, 2006. 612 с.

2. Васиньова Н.С. Розвиток теорії управління вищими навчальними закладами в Україні (остання чверть XX - початок XXI століття) : автореф. дис. на здобуття наук. ступ. канд. пед. наук за спеціальністю 13.00.06. Державний заклад «Луганський національний університет імені Тараса Шевченка». Старобільськ, 2019. 23 с.

3. Заклади вищої освіти. Державна служба статистики. URL: http://www.ukrstat.gov.ua/ (дата звернення: 24.05.19.)
4. Наукові основи управління школою / за ред. Г.В. Єльникової. Харків : ХДШ, 1991. 170 с.

5. Повышение квалисрикации педагогических кадров / под ред. И.Ф. Жерносека, М.Ю. Красовицкого, С.В. Крисюка. Київ : Освіта. 1992. 190 с.

6. Про затвердження переліку паспортів у галузі педагогічних наук : Постанова президії ВАК України від 14.09.2006 р. № 6-06/8. URL: http://consultant. parus.ua/?doc $=0320$ SBFC10\&abz=4WXEP. (дата звернення: 04.05.19.)

7. Про опублікування результатів дисертацій на здобуття наукових ступенів доктора і кандидата наук : Наказ Міністерства освіти і науки, молоді та спорту України № 1112 від 12.12.2012 p. URL: h t t p s: //zakon.rada.gov.ua/laws/s how / z1851-12\#n26 (дата звернення: 24.05.19.).

8. Про опублікування результатів дисертацій на здобуття наукових ступенів доктора і кандидата наук та про їх апробацію : Наказ ВАК України № 178 від 04.04.2000 p. URL: https://zakon.rada.gov.ua/laws/ show/z0431-00 (дата звернення: 24.05.19.)

9. Ситар І.В. Розвиток теорії та технологій наукового управління загальноосвітніми навчальними закладами в Україні (1991-2016 роки ) : дис. ... канд. пед. наук : 13.00.06. Київ, 2018. 223 с. 